\title{
Analysis of wayside energy storage devices for DC heavy rail transport
}

\author{
Petru Valentin Radu ${ }^{1, *}$, and Zbigniew Drazek $^{1}$ \\ ${ }^{1}$ Warsaw University of Technology, Institute of Electric Power Engineering, Electric Traction Division, \\ ul. Koszykowa 75, 00-662, Warsaw, Poland
}

\begin{abstract}
The proposed paper presents the possibility of using the wayside energy storage devices (WESD) for the DC Heavy Rail Transport treating the design, costs and payback time. Moreover a case study comparison for the use of wayside energy storage devices on the heavy transport at the supply voltage of $3.3 \mathrm{kV} \mathrm{DC}$ is presented. A method of sizing the energy storage devices using vehicle characteristics, traction power supply and running timetable is presented. The paper also presents the cost analysis for the most commonly used energy storage devices and the payback time.
\end{abstract}

\section{Introduction}

Nowadays most of the traction vehicles have the ability of regenerative braking. The energy resulted from the braking process is used by other vehicle located in the vicinity of the braking vehicle. If the receiving vehicle is not able to receive the entire energy then it is lost on braking resistors to keep the line voltage under the limits. Different types of energy storage devices are proposed for storing the resulted braking energy like: batteries, supercapacitors, flywheels, superconducting energy storage systems or a combination of them [1, 2, and 3]. Beside the main scope of saving energy the energy storage devices can improve the train traction characteristic, the line voltage and can provide with longer distances between the traction substation supplies $[4,5]$.

The energy storage devices are widely used in the light transport and there are many research papers and studies detailing their design, control, effectiveness and payback time. The maximum power required for the light transport vehicles (metro, tram) is around $1.5 \mathrm{MW}$ compared with heavy rail trains that can be up to $6 \mathrm{MW}$ [6]. In theory the heavy rail trains could save more energy if we consider the power needed for powering them and the longer braking distances. If wayside energy storage devices are used, there is no restriction and constraints regarding the size and location allowing us to freely design those according with the power demanded.

\section{Applications of wayside energy storage devices}

The lead acid battery has been used for more than 150 years [7]. The first lead acid battery used for the electrified transport was called "battery post". They were used in Japan from 1912 to 1927 on Shin-etsu Line. The battery was installed at the Maruyama and Yagasaki traction substation. The space required for battery installation was $20 \%$ bigger than that for substation electrical equipment. The installed battery capacity was $1332 \mathrm{Ah}$ and rated voltage $624 \mathrm{~V}$. The scope of battery use was to suppress the voltage drop [8].

A Ni-MH battery produced by Kawasaki Heavy Industry has been successfully used for wayside light rail application. The batteries Kawasaki Gigacell used for Osaka Subway improved the minimum line voltage from $703 \mathrm{~V}$ to $718 \mathrm{~V}$ and reduced the voltage spikes from $939 \mathrm{~V}$ to $854 \mathrm{~V}$ [9].

In table 1 is presented examples were the batteries Kawasaki Gigacell was used [10].

Table 1. Kawasaki Gigacell applications.

\begin{tabular}{|l|c|c|c|}
\hline Location & $\begin{array}{c}\text { Year of } \\
\text { installation }\end{array}$ & $\begin{array}{c}\text { Battery } \\
\text { capacity }\end{array}$ & $\begin{array}{c}\text { Installation } \\
\text { scope }\end{array}$ \\
\hline $\begin{array}{l}\text { New York } \\
\text { Subway }\end{array}$ & 2010 & $367 \mathrm{kWh}$ & $\begin{array}{c}\text { Verification } \\
\text { tests }\end{array}$ \\
\hline Osaka Subway & 2011 & $205 \mathrm{kWh}$ & $\begin{array}{c}\text { Power } \\
\text { savings }\end{array}$ \\
\hline $\begin{array}{l}\text { Washington } \\
\text { D.C. Subway } \\
\text { (WMATA) }\end{array}$ & 2012 & $385 \mathrm{kWh}$ & $\begin{array}{c}\text { Verification } \\
\text { tests }\end{array}$ \\
\hline $\begin{array}{l}\text { Tokyo } \\
\text { Monorail, } \\
\text { Shinagawa } \\
\text { Substation }\end{array}$ & March 2013 & $203 \mathrm{kWh}$ & $\begin{array}{c}\text { Power } \\
\text { savings }\end{array}$ \\
\hline $\begin{array}{l}\text { Osaka Subway } \\
\text { Sapporo }\end{array}$ & 2013 & $204 \mathrm{kWh}$ & $\begin{array}{c}\text { Power } \\
\text { savings }\end{array}$ \\
\hline $\begin{array}{l}\text { Subway } \\
\text { Tokyo } \\
\text { Monorail, } \\
\text { Tamagawa } \\
\text { Substation }\end{array}$ & March 2014 & $203 \mathrm{kWh}$ & $\begin{array}{c}\text { Power } \\
\text { savings }\end{array}$ \\
\hline
\end{tabular}

\footnotetext{
${ }^{*}$ Corresponding author: petru.radu@ee.pw.edu.pl
} 
Lithium ion batteries produced by Hitachi was successfully tested on Myodani substation of the Seishin-Yamate Line of the Kobe city Subways in 2004 by Kobe Municipal Transportation Bureau. The rated power of the system was $1000 \mathrm{~kW}$ and the rated energy $37.4 \mathrm{kWh}$. The role of energy storage device was to absorb regenerative power. In parallel with the storage devices, the invertor equipment was used to check if they could operate together and no interference was noticed. It was noticed that the installation of the system can save more than $10 \%$ of the energy for power consumption [8].

In 2011, in South Korea on the Seoul Metro Line number 9 a stationary energy storage device was installed produced by Hitachi with lithium ion battery at three substation 903 (0.3MW inverter), 909 (1MW storage system) and 921 (1MW storage system). The estimation for the annual power savings on the substation 921 was $510 \mathrm{MWh}$. During the operation in the first month the energy saved was $94 \mathrm{MWh}$ which surpassed the initial expectations [11].

First stationary energy storage device on electrified railway using a flywheel was introduced in 1988 in Japan. The stationary storage device was installed at the Zushi substation by Keihin Electric Express Railway. The device was able to convert regenerative energy to mechanical energy using a generator motor and converter and back to electrical energy. The total power of the system was $2000 \mathrm{~kW}$ and was able to store up to $25 \mathrm{kWh}$ energy. The energy saved by the storage devices was believed to be around $12 \%[8]$.

\section{Simulation of a DC heavy rail transport}

Figure 1 gives the assumed line profiles including the stations and substations.

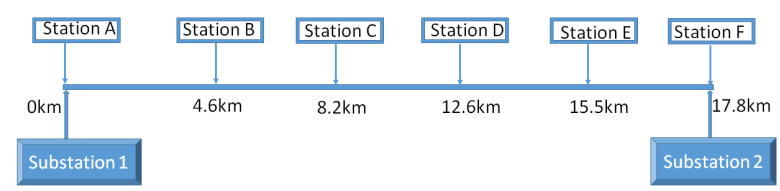

Fig. 1. Simulation line profile.

In table 2 the assumed specification is presented for the vehicle and the line.

Table 2. Simulation parameters.

\begin{tabular}{|l|c|c|}
\hline Parameter & Unit & Quantity \\
\hline Track length & $\mathrm{km}$ & 17.8 \\
\hline Catenary and rail resistance & $\Omega / \mathrm{km}$ & 0.07 \\
\hline Substations internal resistance & $\Omega$ & 0.21 \\
\hline System Voltage & $\mathrm{kV} \mathrm{DC}$ & 3.3 \\
\hline Number of stops & - & 6 \\
\hline Number of trains & - & 1 \\
\hline Train mass & $\mathrm{t}$ & 120 \\
\hline Maximum train speed & $\mathrm{km} / \mathrm{h}$ & 120 \\
\hline Average train speed & $\mathrm{km} / \mathrm{h}$ & 80 \\
\hline $\begin{array}{l}\text { Average train acceleration / } \\
\text { deceleration rate }\end{array}$ & $\mathrm{m} / \mathrm{s}^{2}$ & 0.8 \\
\hline
\end{tabular}

If we consider a train running from Station A to Station $\mathrm{F}$ the train voltage, current and power simulation results are presented in figure 2 . Train simulation was provided in the train simulation program prepared by Electric Traction Division of the Warsaw University of Technology $[12,13]$.

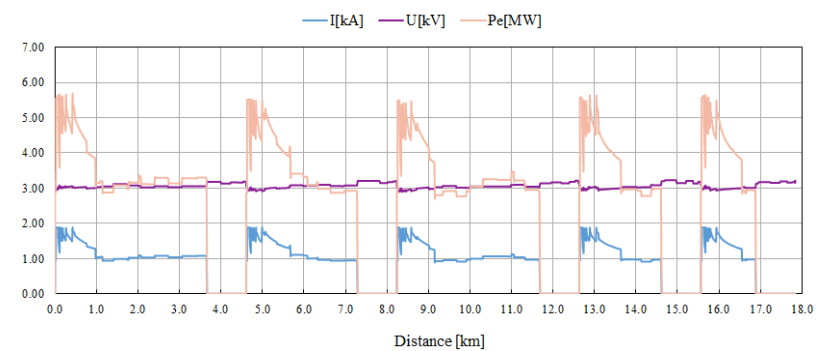

Fig. 2. Simulation results for the train running between Station A and Station F.

The results of the simulation for a train travelling from Station A to Station F are presented in table 3.

Table 3. Simulation results for the train running between Station A and Station F.

\begin{tabular}{|l|c|c|c|c|}
\hline Stations & $\begin{array}{c}\text { Track } \\
\text { length } \\
{[\mathbf{k m}]}\end{array}$ & $\begin{array}{c}\text { Total } \\
\text { Energy } \\
\text { used } \\
{[\mathbf{k W h}]}\end{array}$ & $\begin{array}{c}\text { Energy used } \\
\text { per km } \\
{[\mathbf{k W h} / \mathbf{k m}]}\end{array}$ & $\begin{array}{c}\text { Average } \\
\text { power } \\
{[\mathbf{M W}]}\end{array}$ \\
\hline A-B & 4.6 & 132.2 & 28.73 & 2.86 \\
\hline B-C & 3.6 & 106.3 & 29.52 & 2.79 \\
\hline C-D & 4.4 & 121 & 27.5 & 2.77 \\
\hline D-E & 2.9 & 83.7 & 28.86 & 2.65 \\
\hline E-F & 2.3 & 68.1 & 29.6 & 2.6 \\
\hline Total & $\mathbf{1 7 . 8}$ & $\mathbf{5 1 1 . 3}$ & $\mathbf{2 8 . 7 2}$ & $\mathbf{2 . 7 3}$ \\
\hline
\end{tabular}

Figure 3 shows the train movement diagram used for operation calculations for a 5 minute headway and 1 minute stop at each station.

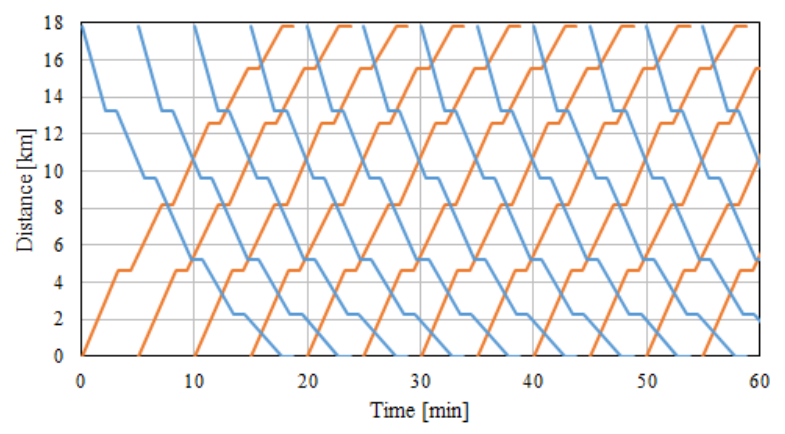

Fig. 3. Assumed train movement diagram for 5 minute headway.

From figure 3, the train operation was calculated for one year and presented in table 4 .

The average train speed for the simulation was considered $80 \mathrm{~km} / \mathrm{h}$ with a train mass of $120 \mathrm{t}$. From figure 4 we can conclude that the wayside energy storage system should be capable of absorbing minimum energy of 38.4 MJ $(10.7 \mathrm{kWh})$. The charging / discharging current for the WESD is considered $1 \mathrm{kA}$. If we consider the WESD power $3 \mathrm{MW}$ and the absorbed energy of $40 \mathrm{MJ}$ the charging time for the WESD is $20 \mathrm{~s}$ 
$(40 \mathrm{MJ} / 3 \mathrm{MW}=13 \mathrm{~s})$. For $13 \mathrm{~s}$ charging time and $2 \mathrm{C}$ current the depth of discharge (DOD) is $0.7 \%$ $(13 * 2 / 3600=0.7 \%)$, for $3 \mathrm{C}$ current the DOD is $1.1 \%$ $(13 * 3 / 3600=1.1 \%)$ and for $5 \mathrm{C}$ current the DOD is $1.8 \%$ $(13 * 5 / 3600=1.8 \%)$.

Table 4. Assumed train operation for a calendar year.

\begin{tabular}{|l|c|c|c|}
\hline Time & Headway & $\begin{array}{c}\text { Cycles } \\
\text { per Day }\end{array}$ & $\begin{array}{c}\text { Total } \\
\text { cycles }\end{array}$ \\
\hline $\begin{array}{l}\text { Peak hours (6-9AM } \\
\text { and 4-7PM) }\end{array}$ & 5 minutes & 144 & 52560 \\
\hline $\begin{array}{l}\text { Off - peak hours and } \\
\text { weekends }\end{array}$ & 15 minutes & 128 & 46720 \\
\hline $\begin{array}{l}\text { Between 1AM and } \\
\text { 3PM }\end{array}$ & $\begin{array}{l}\text { No train } \\
\text { services }\end{array}$ & - & - \\
\hline \multicolumn{3}{|l|}{ Total } & $\mathbf{9 9 2 8 0}$ \\
\hline
\end{tabular}

\section{Calculation of the energy that can be saved}

The Polish transport company SKM provided test of braking with regeneration on $3.3 \mathrm{kV}$ DC trains manufactured by Polish company Newag S.A in April 2012 [14]. The measurements was taken in train with the energy meter LE3000 Elester. Table 5 presents the measurement results provided by SKM.

Table 5. Measurements results provided by SKM.

\begin{tabular}{|l|c|c|c|}
\hline Train Type & $\begin{array}{c}\text { EZT19 } \\
\text { WE }\end{array}$ & $\begin{array}{c}\text { EZT27 } \\
\text { WE }\end{array}$ & $\begin{array}{c}\text { EZT35 } \\
\text { WE }\end{array}$ \\
\hline Max power & $3.5 \mathrm{MW}$ & $4 \mathrm{MW}$ & $4 \mathrm{MW}$ \\
\hline Train mass & $190 \mathrm{t}$ & $190.5 \mathrm{t}$ & $197 \mathrm{t}$ \\
\hline $\begin{array}{l}\text { Maximum train } \\
\text { speed }\end{array}$ & $130 \mathrm{~km} / \mathrm{h}$ & $160 \mathrm{~km} / \mathrm{h}$ & $160 \mathrm{~km} / \mathrm{h}$ \\
\hline $\begin{array}{l}\text { Average train } \\
\text { speed }\end{array}$ & $42 \mathrm{~km} / \mathrm{h}$ & $41 \mathrm{~km} / \mathrm{h}$ & $36.8 \mathrm{~km} / \mathrm{h}$ \\
\hline Track length & $\begin{array}{c}\text { Approx. } \\
35.5 \mathrm{~km}\end{array}$ & $\begin{array}{c}\text { Approx. } \\
23 \mathrm{~km}\end{array}$ & $\begin{array}{c}\text { Approx. } \\
29 \mathrm{~km}\end{array}$ \\
\hline $\begin{array}{l}\text { Stations } \\
\text { Pruszkow }- \\
\text { Sulejowek } \\
\text { Miłosna }\end{array}$ & $\begin{array}{c}\text { Zarszawa } \\
-\end{array}$ & $\begin{array}{c}\text { Warszawa } \\
\text { Zachodnia } \\
(\text { Platform } 8) \\
\text { Legionowo } \\
\text { Piaski }\end{array}$ \\
\hline $\begin{array}{l}\text { Total energy } \\
\text { used }\end{array}$ & $362.2 \mathrm{kWh}$ & $302.9 \mathrm{kWh}$ & $329.7 \mathrm{kWh}$ \\
\hline $\begin{array}{l}\text { Total energy } \\
\text { saved }\end{array}$ & $129.9 \mathrm{kWh}$ & $59.4 \mathrm{kWh}$ & $121.5 \mathrm{kWh}$ \\
\hline $\begin{array}{l}\text { Percent energy } \\
\text { saved }\end{array}$ & $35.31 \%$ & $19.58 \%$ & $37 \%$ \\
\hline $\begin{array}{l}\text { Average } \\
\text { energy used } \\
\text { per km }\end{array}$ & $\begin{array}{c}10.2 \mathrm{kWh} / \mathrm{k} \\
\mathrm{m}\end{array}$ & $\begin{array}{c}13.17 \mathrm{kWh} / \\
\mathrm{km}\end{array}$ & $\begin{array}{c}11.37 \mathrm{kWh} / \mathrm{k} \\
\mathrm{m}\end{array}$ \\
\hline $\begin{array}{l}\text { Average } \\
\text { energy saved } \\
\text { per km }\end{array}$ & $\begin{array}{c}3.1 \mathrm{kWh} / \mathrm{k} \\
\mathrm{m}\end{array}$ & $\begin{array}{c}2.58 \mathrm{kWh} / \mathrm{k} \\
\mathrm{m}\end{array}$ & \begin{tabular}{c}
$4.19 \mathrm{kWh} / \mathrm{km}$ \\
\hline
\end{tabular} \\
\hline
\end{tabular}

The total energy that can be recovered by the WESD can be calculated with the formula:

$$
E_{\text {WESD }}=E_{\text {Breake }}-E_{\text {Aux }}-E_{\mathrm{L}}
$$

where:

$\mathrm{E}_{\mathrm{WESD}}$ - potential energy that can be recovered by the storage device $[\mathrm{kWh}]$,
$E_{\text {Breake }}$ - total energy resulted from the braking vehicle depending on the mass, speed and brake force [kWh], $E_{\text {Aux }}$ - energy recovered by the braking vehicle and used for auxiliary supply (lighting, ventilation, heating etc.) [kWh],

$\mathrm{E}_{\mathrm{L}}$ - energy line loses $[\mathrm{kWh}]$.

If we consider that the traction vehicle loses only mechanical energy and we have only kinetic energy $\left(E_{\text {Breake }}=E_{k}\right)$ we can use the following formula to determine the energy resulted from braking:

$$
E_{k}=m \times V^{2} / 2
$$

where:

$\mathrm{V}$ - the vehicle velocity in $[\mathrm{km} / \mathrm{h}]$,

$\mathrm{m}$ - the vehicle mass in $[\mathrm{kg}]$,

$\mathrm{E}_{\mathrm{k}}$ - the kinetic energy in $[\mathrm{kWh}]$.

Figure 4 shows estimated braking energy for different vehicle mass and velocity calculated according with formula (2).

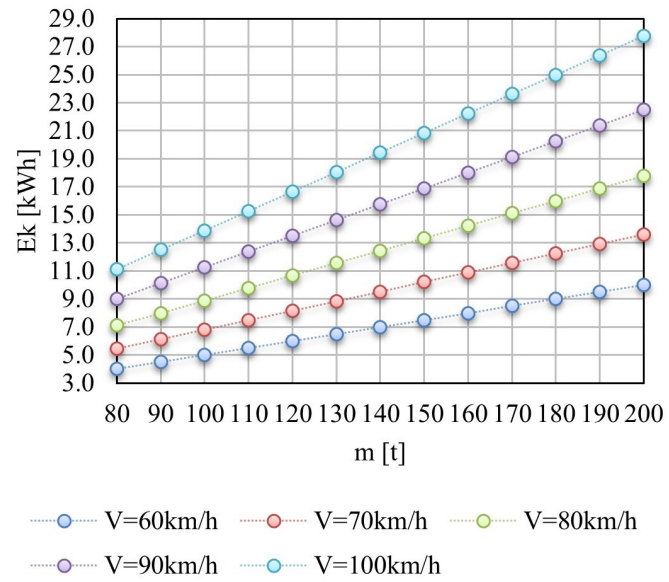

Fig. 4. Braking energy in $\mathrm{kWh}$.

The power needed for the auxiliary train equipment can be around $40 \mathrm{~kW}$ depending on the weather conditions (cold or hot), period of the day (day or night). We assume the energy recovered by the braking vehicle to be around $3 \mathrm{kWh}$.

Depending of the location of the WESD and the braking current we can have different catenary losses.

$$
\Delta E_{L}=R \cdot \int_{0}^{t} I^{2} d t
$$

where:

$\Delta \mathrm{E}_{\mathrm{L}}$ - energy losses in wires [W] function of time $\mathrm{t}[\mathrm{s}]$, $\mathrm{R}$ - resistance of the line $[\Omega]$, I - the load current $[\mathrm{A}]$.

If we consider the energy loses in catenary around $10 \%$ of the braking energy $10.7 \mathrm{kWh}$ according to figure 5 we have approximately $1.1 \mathrm{kWh}$ catenary loses for a maximum distance of $17.8 \mathrm{~km}$ between the braking train and the WESD. 
According to figure 4 and figure 5 the potential energy that can be recovered by the storage device is approximately $6.6 \mathrm{kWh}(10.7 \mathrm{kWh}-3 \mathrm{kWh}-1.1 \mathrm{kWh}=$ $6.6 \mathrm{kWh})$ considering that there is no other train to recover the braking energy which is around $60 \%$ from the braking energy that can be recovered.

The recovered braking energy can take values from $5 \%$ to $30 \%$ from the total consumed energy depending on the receptivity of the other trains to consume the energy. The energy for a train to travel from Station A to Station $\mathrm{F}$ is $511 \mathrm{kWh}$. For the worst case scenario where the recovered energy is $5 \%$ we have $25 \mathrm{kWh}$ potential recovered energy divided between the catenary losses, auxiliary train equipment and the WESD.

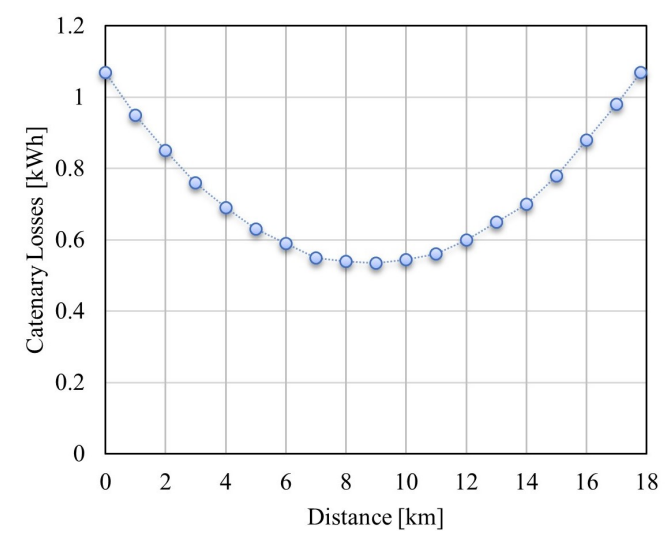

Fig. 5. Catenary loses for different location of the WESD in kWh.

From the above results the WESD can recover around $15 \mathrm{kWh}(60 \%$ from $25 \mathrm{kWh})$ for a train travel between Station A and Station F. For 99280 cycles per year in both directions, theoretically we can save up to 1490MWh/year.

The $\mathrm{kWh}$ in Poland costs around 0.09 US $\$$ for industry [15] which results on a potential saving of 134 000 US \$ per year. For a 10 years calendar life of WESD system we can calculate the money saved as 1.34 million US $\$(0.134$ million US $\$ * 10$ years $=1.34$ million US $\$)$.

\section{Designing of the energy storage devices}

To directly connect the energy storage devices we need to design them to the voltage line to avoid electrical separation.

\subsection{Lead acid batteries}

The Hitachi LL1500-WS battery [16] has 2V and $1500 \mathrm{Ah}$ per cell with a recommended maximum discharging current of $900 \mathrm{~A}$, a maximum of charging current of 450A and energy capacity of $3 \mathrm{kWh}(1500 \mathrm{Ah}$ * $2 \mathrm{~V} / 1000=3 \mathrm{kWh}$ ). To connect the WESD to the $3.3 \mathrm{kV}$ we need 1650 batteries $(2 \mathrm{~V} * 1650$ batteries $=$ $3.3 \mathrm{kV}$ ) in series. The energy capacity of the unit is $5 \mathrm{MWh}(3 \mathrm{kWh} * 1650$ batteries $=5 \mathrm{MWh})$. Because the maximum discharge current is $900 \mathrm{~A}$ the power rating for the unit is limited to $3 \mathrm{MW}(3300 \mathrm{~V} * 900 \mathrm{~A} / 1000=$ $3 \mathrm{MW}$ ).

The number of cycles given by Hitachi for a $70 \%$ DOD is 4500 cycles. For $0.7 \%$ DOD number of cycles is 450000 cycles and for $1.1 \%$ DOD number of cycles is 286000 cycles. If we consider the calendar life of the battery to be 10 years, the number of cycles should be sufficient because on peak hours the braking energy is transferred between trains and the DOD is much smaller than calculated. For a DOD of $1.1 \%$ the maximum energy that can be saved by the WESD is $55 \mathrm{kWh}$.

The price given by Hitachi Chemical for the battery is approximately $300 \mathrm{US} \$$ per $\mathrm{kWh}$ [17]. If we consider the battery management system to cost 0.5 million US $\$$ the WESD cost is around 2.5 million US $\$$ (for 1650 batteries).

\subsection{Nickel-metal hydride ( $\mathrm{Ni}-\mathrm{MH}$ ) batteries}

The Kawasaki Gigacell battery [10] has 36V (30cells * $1.2 \mathrm{~V}=36 \mathrm{~V}$ ) and $150 \mathrm{Ah}$ per battery with a charging/discharging recommended maximum current of $750 \mathrm{~A}(5 \mathrm{C})$ and energy capacity of $5.4 \mathrm{kWh}(150 \mathrm{Ah} *$ $36 \mathrm{~V} / 1000=5.4 \mathrm{kWh})$. To connect the WESD to the $3.3 \mathrm{kV}$ we need 91 batteries $(36 \mathrm{~V} * 91$ batteries $=$ $32730 \mathrm{~V})$ in series. The energy capacity of the unit is $491,4 \mathrm{kWh}(5.4 \mathrm{kWh} * 91$ batteries $=491,4 \mathrm{kWh})$. The power rating for the unit at a 5C maximum charge/discharge rate is $2.46 \mathrm{MW}(3276 \mathrm{~V} * 750 \mathrm{~A} / 1000$ $=2.46 \mathrm{MW}$ ).

If we want to capture all the braking energy we need to design the WESD capable of absorbing 40MJ. For 2 units connected in parallel we have $1.5 \mathrm{kA}$ maximum current at a $5 \mathrm{C}$ maximum charge/discharge rate per unit. The energy capacity of the system is $983 \mathrm{kWh}$ $(491.4 \mathrm{kWh} * 2=983 \mathrm{kWh})$. The power rating for the system at a $5 \mathrm{C}$ maximum charge/discharge rate is $4.9 \mathrm{MW}(3276 \mathrm{~V} * 750 \mathrm{~A} * 2 / 1000=4.9 \mathrm{MW})$.

The number of cycles given by Kawasaki for a $0.33 \%$ DOD is 2 million. For $0.7 \%$ DOD number of cycles is 943000 cycles and for $1.8 \%$ DOD number of cycles is 367000 cycles. If we consider the calendar life of a battery as 10 years for our system the number of cycles should be sufficient because on peak hours the braking energy is transferred between trains and the DOD is much smaller than calculated. For a DOD of $1.8 \%$ the maximum energy that can be saved by the WESD is $17.7 \mathrm{kWh}$.

For a battery price of 25000 US $\$$ and 0.5 million US $\$$ cost assumed for the battery management system the cost of the WESD is around 5.1 million US \$ (for 182batteries).

\subsection{Lithium Ion (Li-ion) batteries}

The Hitachi CH-75-6 battery [18] has 22.2V (3.7Vcell * 6 cells $=22.2 \mathrm{~V}$ ) and $75 \mathrm{Ah}$ per pack with a charging/discharging recommended maximum current of $3 \mathrm{C}(225 \mathrm{~A})$ and energy capacity of $5 \mathrm{kWh}(225 \mathrm{Ah} *$ $22.2 \mathrm{~V} / 1000=5 \mathrm{kWh})$. To connect the WESD to the $3.3 \mathrm{kV}$ we need 148 batteries $(22.2 \mathrm{~V} * 148$ batteries $=$ 
$3.3 \mathrm{kV})$ in series. The energy capacity of the unit is $4.95 \mathrm{MWh}(5 \mathrm{kWh} * 148 \mathrm{batteries}=740 \mathrm{kWh})$. The power rating for the system at a $3 \mathrm{C}$ maximum charge/discharge rate is $4.9 \mathrm{MW}(3286 \mathrm{~V} * 225 \mathrm{~A} / 1000=739 \mathrm{~kW})$.

If we want to capture all the braking energy we need to design the WESD capable of absorbing 40MJ. For 4 units connected in parallel we have 900A maximum current at a $3 \mathrm{C}$ maximum charge/discharge rate for unit. The energy capacity of the system is $3 \mathrm{MWh}(740 \mathrm{kWh} *$ $4=3 \mathrm{MWh})$. The power rating for the system at a $3 \mathrm{C}$ maximum charge/discharge rate is $3 \mathrm{MW}(3286 \mathrm{~V} * 225 \mathrm{~A}$ * $6 / 1000=3 \mathrm{MW}$ ).

The number of cycles given by Hitachi for a $75 \%$ DOD is 4000 cycles. For $0.7 \%$ DOD number of cycles is 428000 cycles and for $1.1 \%$ DOD number of cycles is 273000 cycles. The calendar life of the battery given by Hitachi is 10 years the number of cycles should be sufficient because on peak hours the braking energy is transferred between trains and the DOD is much smaller than calculated. For a DOD of $1.1 \%$ the maximum energy that can be saved by the WESD is $33 \mathrm{kWh}$.

The price given by Hitachi Chemical for the battery is approximately 900 US \$ per $\mathrm{kWh}$ [17] (4500 US \$ per module) excluding the battery management system that can be assumed to cost 0.5 million US \$. If we consider a cost of 7000 US $\$$ per module the WESD cost is around 4.8million US \$ (for 592batteries).

\subsection{Supercapacitors (SC)}

The Maxwell BMOD0063 P125 B08 supercapacitors [19] has $125 \mathrm{~V}$ (48cells), 140A continuous current and with a charging/discharging recommended maximum current of 1900A and energy capacity of 144Wh (3Wh * 48 cells $=144 \mathrm{Wh})$. Because the ESR can increase up to $100 \%$ during 10 years of service we have to reduce the continuous current to $100 \mathrm{~A}$. To connect the WESD to the $3.3 \mathrm{kV}$ we need 27 supercapacitors $(125 \mathrm{~V} *$ 27 supercapacitors $=3.3 \mathrm{kV}$ ) in series. The energy capacity of the unit is $3.9 \mathrm{kWh}(144 \mathrm{Wh} *$ 27 supercapactiors $=3.9 \mathrm{kWh}$ ). The power rating for the system at a $100 \mathrm{~A}$ charge/discharge current is $0.38 \mathrm{MW}$ $(3375 \mathrm{~V} * 100 \mathrm{~A} / 1000=0.38 \mathrm{MW})$.

If we want to capture all the braking energy we need to design the WESD capable of absorbing 40MJ. For 10 units connected in parallel we have $1 \mathrm{kA}$ continuous current and a maximum charge/discharge current of $19 \mathrm{kA}$. The energy capacity of the system is $39 \mathrm{kWh}$ $(3.9 \mathrm{kWh} * 10=39 \mathrm{kWh})$. The system power rating for $1 \mathrm{kA}$ continuous current is $4.9 \mathrm{MW}(3276 \mathrm{~V} * 1000 \mathrm{~A} * 10$ $/ 1000=3.3 \mathrm{MW})$.

The number of cycles for charge/discharge given by Maxwell is 1 million times at $25^{\circ} \mathrm{C}$ with a live period of 10 years. The maximum energy that can be saved by the WESD is $39 \mathrm{kWh}$.

The price for the BMOD0063 P125 B08 is approximately 5000 US \$ not including the converter and the voltage equalizing circuit which can be estimated to cost around 0.5 million US \$ the WESD cost is around 1.9 million US \$ (for 270 supercapacitors).

\subsection{Flywheel}

The Vycon VDC flywheel [20] has input voltage regulated between $400 \mathrm{~V}$ to $600 \mathrm{~V}, 500 \mathrm{~kW}$ output power and can store up to $7.5 \mathrm{MJ}$.

To connect the WESD to the $3.3 \mathrm{kV}$ we need 6 modules $(600 \mathrm{~V} * 6$ modules $=3.3 \mathrm{kV})$ in series.

If we want to capture all the braking energy we need to design the WESD capable of absorbing 40MJ. For 6 units connected in parallel we have $45 \mathrm{MJ}$ (6units * $7.5 \mathrm{MJ}=45 \mathrm{MJ}$ ) and $3 \mathrm{MW}$ power.

The Vycon VDC flywheel has 20 year operational live with low maintenance (equipped with magnetic bearing).

The price for the flywheel is assumed 1 million US \$ / MW and 0.5million US $\$$ for the control circuit which give a total cost of the WESD 3.5 million US \$.

\section{Conclusion}

In the article an example was presented on how to calculate the train braking energy. Simulation was provided with scope of calculation the energy needed for a train to run on an example line. The main cost for the WESD is the energy storage medium. The design and cost estimation was made for a period of 10 years calendar life given by the manufacturers for the batteries.

For a 10 years period the energy that can be saved for the example provided is $15 \mathrm{GWh}$ which is 1.34 million US \$. For 10 years life time the cost for the WESD with battery is 2.5 million US \$ for lead acid, 5.1 million US $\$$ for Ni-MH, 4.8 million US \$ for Li-ion, 1.9 million US $\$$ for WESD with SC and 3.5 million US \$ for WESD with flywheel. When calculating the total cost of the WESD the installation, building premises, cooling and heating or maintenance were not taken into account; these factors will considerably increase the total costs.

The revised WESD from the example provided does not save enough energy to justify the installation by the customer. The most probable WESD that will be used on electrified heavy rail transport in the future will be with $\mathrm{SC}$ because it is the most cost effective.

\section{References}

1. P. Radu and A. Szelag, A Cuk converter integrated with lead-acid battery and supercapacitor for stationary applications, Proceeding of IEEE 18th International Scientific Conference on Electric Power Engineering (EPE), Kouty nad Desnou, Czech Republic, 1-6 (2017).

2. N. Ghaviha, J. Campillo, M. Bohlin, E. Dahlquist, Review of Application of Energy Storage Devices in Railway Transportation, The 8th International Conference on Applied Energy - ICAE, Energy Procedia, 105, 4561 4568 (2017).

3. P. Radcliffe, J. S. Wallace, L. H. Shu, Stationary Applications of Energy Storage Technologies for Transit Systems, IEEE Electrical Power \& Energy Conference, 17 (2010).

4. T. Ratniyomchai, S. Hillmansen, P. Tricoli, Optimal Capacity and Positioning of Stationary Supercapacitors for Light Rail Vehicle Systems, International Symposium 
on Power Electronics, Electrical Drives, Automation and Motion, IEEE, 807-812 (2014).

5. H. Kobayashi, T. Saito, K. Kondo, A Study on a Method to Design Energy Capacity of Wayside Energy Storage Devices in DC-electrified Railway Systems, Power Electronics and Applications EPE ECCE-Europe, 1-9, (2015).

6. J. G. Yu, Martin P. Schroeder, D. Teumim, Utilizing Wayside Energy Storage Substations in Rail Transit Systems - Some Modelling and Simulation Results, APTA Rail Conference, 1-8 (2010)

7. P.T. Moseley, D.A.J. Rand, In celebration of the sequicentennial of the lead-acid battery, Journal Of Power Sources, 195, 4423, (2010).

8. A. Okui, S. Hase, H. Shigeeda, T. Konishi, T.Yoshi, Application of Energy Storage System for Railway Transportation in Japan, Proc. Int. Conf. Power Electronics Conf. IPEC, Sapporo, Japan, 3117-3123 (2010).

9. M. Ouattara, J. G. Yu, WMATA Energy Storage Demonstration Project, FTA Report 0086 Federal Transit Administration, http://www.fta.dot.gov/research (2015).

10. http://www.khi.co.jp/english/gigacell/. Retrieved on 201706-18.

11. H. Takahashi, K. Aoki, A. Maoka, Y. Ik Kim, Current and Future Applications for Regenerative Energy Storage System, Hitachi Review, 61, 7, 336-340 (2012).

12. A. Szelag, T. Maciolek, Z. Drazek, M. Lewandowski, Conditions for the effective use of traction substations with possible return of trains regenerative braking energy into a power network in a $3 \mathrm{kV}$ DC supply system, Logistyka 3, 4683-4692 (2015).

13. A. Szelag, The influence of the voltage in the $3 \mathrm{kV} D C$ traction network on the energy and traction parameters of supplied vehicles, Wyd. INW Spatium, Radom, 158, (2013).

14. http://www.skm.warszawa.pl/dane-technicznepojazdow.html, Retrieved on 2017-06-18.

15. http://ec.europa.eu/eurostat/statistics-explained /index.php/Energy_price_statistics, Retrieved on 2017-0618.

16. H. Kodoma, Electrical energy storage devices \& systems, Hitachi Chemical Technical Report, 57, 6-15 (2015).

17. M. Sawato, Credit Suisse, Asia Pacific / Japan, Equity Research, Specialty Chemicals (Chemicals/Textiles (Japan) / Market Weight, Hitachi Chemical, 4217 (2015).

18. M. Yoshida, T. Hirasawa, K. Sumiya. Electrical energy storage devices \& systems, Hitachi Chemical Technical Report, 55, 4-8 (2013).

19. http://www.maxwell.com/images/documents/125vmodule ds_1014696-7.pdf, Retrieved on 2017-06-18.

20. http://www.ampower.com.tw/wp-content/ uploads/2014/pdf/brochure-VDC\%20flywheel.pdf, Retrieved on 2017-06-18.

21. A.J.C. Schmeitz, A Semi-Empirical Three-Dimensional Model of the Pneumatic Tyre Rolling over Arbitrarily Uneven Road Surfaces, PhD thesis, TU Delft (2004). 